\title{
Penilaian Kondisi Bendungan Studi Kasus Bendungan Manggar
}

\author{
Mersianty \\ Program Studi Teknik Sipil \\ Politeknik Negeri Balikpapan, \\ Jl. Soekarno Hatta Km 8, \\ E-mail : mersianty@poltekba.ac.id
}

\begin{abstract}
Material alluvium of water plants and acacia roots that have died, because of suffused accumulating basin water can affects the decrease of water quality and the capacity of the dam. In consequence, needed condition assessment at dam Manggar to determine its maintenance activity. Maintenance System at dam Manggar there is no such inspecting condition procedure of condition assessment until information of dam very limited and not detail, its not yet gave its assessment of dam condition level. This Research focused on arranging the procedure of condition assessment at spillway dam Manggar. Step of condition assessment needs spillway component and sub component input, each of which component will be given wight bases contribution level to function of dam service, and given value of condition index bases inspection of criterion level condition its dam damage. There is 5 criteria of level condition categories damage that compiled at spillway component and each criteria have value from scale $1-5$ so-called value of condition index. Scale 5 are given for good condition and scale 1 are given for failed condition. From result of condition assessment on spillway of the dam Manggar by using method of index condition its got value of condition index $=4,26$, from scale of 1-5 condition index spillway of dam Manggar enters good condition criteria, nevertheless start experience of degradation of condition value until remain to need activity of routine maintenance.
\end{abstract}

Keywords : Dam, Condition assessment, maintenance, method of index condition.

\begin{abstract}
Abstrak
Endapan material dari akar-akar tanaman air dan pohon-pohon akasia yang telah mati, akibat tergenang air waduk dapat berdampak pada penurunan kualitas dan kapasitas tampung waduk. Oleh karena itu diperlukan penilaian kondisi pada bendungan Manggar untuk menentukan kegiatan pemeliharaannya. Sistem pemeliharaan pada bendungan Manggar belum disertai prosedur penilaian kondisi sehingga informasi kondisi bendungan yang diperoleh sangat terbatas, belum sampai pada penilaian tingkat kondisi bendungannya. Penelitian ini fokus pada penyusunan prosedur penilaian kondisi pada pelimpah bendungan Manggar. Tahapan penilaian kondisi memerlukan input komponen dan sub komponen pelimpah dimana masing-masing komponen akan diberi bobot berdasarkan tingkat kontribusi terhadap fungsi layanan bendungan, dan di beri nilai indeks kondisi berdasarkan pemeriksaan kondisi tingkat kriteria kerusakan bangunannya. Terdapat 5 kriteria kategori kondisi tingkat kerusakan yang disusun pada komponen pelimpah dan masing-masing kriteria memiliki nilai dari skala 1 - 5 yang disebut nilai indeks kondisi. Skala 5 diberikan untuk kondisi baik dan skala 1 diberikan untuk kondisi rubuh (hancur). Dari hasil penilaian kondisi pelimpah bendungan manggar dengan menggunakan metode indeks kondisi gabungan diperoleh nilai indeks kondisi $=4,26$, dari skala indeks kondisi 1-5 secara umum kondisi pelimpah bendungan Manggar masuk dalam kriteria kondisi baik, namun mulai mengalami penurunan nilai kondisi sehingga diperlukan tindakan pemeliharaan untuk memperlambat terjadinya penurunan kondisi.
\end{abstract}

Kata Kunci : Bendungan, Penilaian kondisi, Pemeliharaan, Metode indeks kondisi. 


\section{Pendahuluan}

Bendungan Manggar merupakan infrastruktur yang sangat penting bagi masyarakat kota Balikpapan, dibangun pada tahun 1982-1985 melalui dana hibah kerajaan Belanda. Selain untuk memenuhi kebutuhan air baku kota Balikpapan, bendungan Manggar juga berfungsi sebagai konservasi air yaitu mengurangi limpasan permukaan (surface run off) dari hulu sungai agar tidak terjadi banjir di hilir dan untuk pengisian kembali air tanah. Pertumbuhan penduduk kota Balikpapan yang cukup tinggi setiap tahunnya, berdampak pada meningkatnya kebutuhan air baku. Permasalahan krisis air bersih akibat pasokan air dari bendungan Manggar yang tidak mencukupi terutama pada musim kemarau yang cukup panjang, maka pada tahun 1999-2006 dilakukan peningkatan pada bendungan Manggar dengan cara menaikkan tinggi bendungan dari elevasi 7,8 m menjadi elevasi $13,40 \mathrm{~m}$ dengan kapasitas efektif waduk 14,20 juta $\mathrm{m}^{3}$ yang menghasilkan kapasitas produksi 900 1/det pada kondisi normal dan kemampuan produksi pada musim kemarau adalah 160 hari tanpa hujan.

Permasalahan yang ada pada bendungan Manggar saat ini yakni menurunnya kualitas air yang tercemar oleh limbah masyarakat yang beraktivitas di sekitar hulu bendungan dan tumbuhan air yang hidup mengambang di permukaan air waduk. Meskipun secara langsung tidak membahayakan, namun kualitas air yang buruk menyebabkan tingginya biaya-biaya operasi pengolahan air waduk untuk memenuhi kelayakan kualitas air baku.

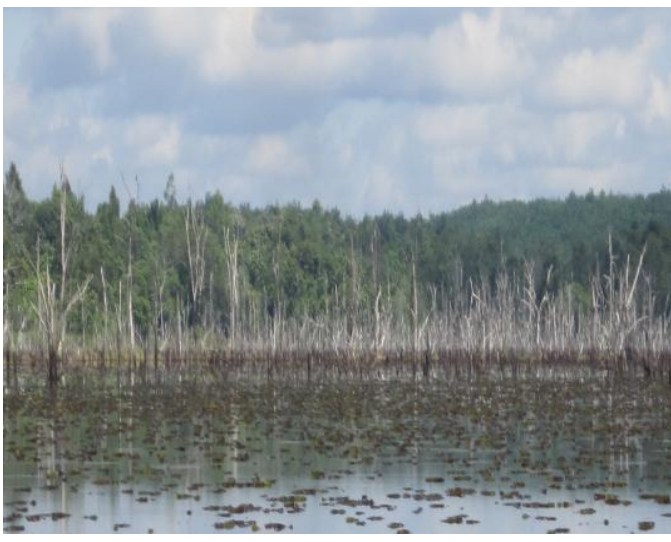

Gambar 1. Kondisi perairan waduk Manggar

Perluasan genangan waduk Manggar setelah dilakukan peningkatan menyebabkan pohon-pohon akasia di kawasan hutan lindung seluas $70 \mathrm{Ha}$, ikut terendam dan mati. Pohon-pohon yang telah mati tidak dapat di tebang dan endapan material dari akar-akar tanaman yang membusuk tidak dikeruk karena terbentur peraturan perijinan pada kawasan hutan lindung, hal ini menyebabkan kapasitas tampung waduk menjadi tidak optimal. Permasalahan yang ada pada waduk Manggar saat ini, tentunya akan membawa dampak terganggunya fungsi operasi waduk dalam menyediakan air baku baik secara kualitas maupun kuantitas, juga kerusakan-kerusakan pada bangunan bendungannya. Untuk tetap menjamin operasi bendungan Manggar dapat berfungsi dengan baik sepanjang umur layanannya, maka sangat diperlukan kegiatan pemeliharaan, yang didahului dengan kegiatan pemeriksaan kondisi bangunan untuk menetapkan kondisi komponen yang harus dipelihara. 
Pedoman pemeliharaan bendungan yang digunakan sebagai panduan dalam pemeliharaan bendungan Manggar saat ini, belum disertai prosedur maupun metode penilaian kondisi yang sesuai dengan fungsi bangunan bendungannya. Sebagai panduan dalam melaksanakan pemeriksaan kondisi bendungan masih terbatas pada formulir-formulir inspeksi yang hanya dapat memberikan informasi kondisi komponen bendungan yang sangat terbatas, belum sampai pada penilaian tingkat kondisi bendungannya.

Oleh karena sistem pemeliharaan bendungan urugan belum didukung suatu prosedur atau standar-standar penilaian kondisi bendungan yang secara umum dapat digunakan di Indonesia, sehingga belum ada acuan penilaian kondisi yang baku dan dapat digunakan oleh pihak pengelola bendungan Manggar. Hal ini menyebabkan pengambilan keputusan untuk menentukan kegiatan-kegiatan pemeliharaan bendungan seringkali terkendala dalam menentukan prioritas kegiatan pemeliharaan yang dibutuhkan dan penggunaan dana-dana pemeliharaan menjadi tidak efektif dan efisien.

\section{Pemeliharaan Infrastruktur}

\subsection{Penurunan Kondisi Bangunan}

Definisi penurunan kondisi dari beberapa kamus secara umum adalah sebagai "sesuatu yang bertambah buruk; terjadi depriasi atau menjadi using". Penurunan kondisi (deteriorasi) menurut E. Aktan et al (1996) adalah suatu perubahan yang terjadi secara gradual dan dalam jangka panjang berdasarkan parameter-parameter yang ditetapkan. Indikasi yang menunjukkan terjadinya penurunan kondisi bendungan adalah terjadinya kerusakan bendungan, baik kerusakan fungsional dan kerusakan struktural. Kerusakan bendungan dapat didefinisikan sebagai setiap kejadian yang dapat menghalangi berfungsinya suatu bendungan sebagaimana mestinya.

Kerusakan pada salah satu komponen berarti kerusakan pada bendungan, karena dapat mengakibatkan tidak berfungsinya komponen lain, sehingga disebut juga kerusakan tidak langsung. Kerusakan fungsional pada bendungan adalah kerusakan yang menyebabkan terganggunya fungsi bendungan, yang dapat berhubungan ataupun tidak dengan kerusakan strukturalnya. Kerusakan fungsional pada bendungan dapat berupa menurunnya kapasitas bendungan yang disebabkan oleh endapan sedimen atau aliran air pada bangunan pelimpah kurang lancar yang disebabkan adanya penghalang tumbuhan vegetasi pada saluran. Kerusakan struktural adalah kerusakan pada struktur komponen bendungan, sebagian atau keseluruhannya yang menyebabkan stabilitas dari komponen bendungan menurun.

Tolok ukur kerusakan dan kegagalan bendungan dijabarkan sebagai tidak dapat berfungsinya bendungan sesuai dengan maksud pembangunannya. Tolak ukur kegagalan bendungan yang di rumuskan adalah sebagai berikut :

1) Waduk tidak dapat berfungsi untuk menampung air sehingga tidak dapat dialirkaan melalui bangunan pengeluaran.

2) Bendungan dan bangunan pelengkapnya tidak bisa mengatur debit yang keluar dari waduk atau terjadinya pengeluaran air dari waduk ke hilir yang tidak terkendali.

3) Bendungan dan bangunan pelengkapnya tidak dapat menyediakan tinggi tekanan air yang cukup bagi keperluan pembangkitan tenaga listrik. Kriteria kerusakan dan kegagalan pada bendungan yang dinilai menurut 
ICOLD (International Commission on Large Dams), adalah sebagai berikut :

1) Keruntuhan tipe 1

Terjadi keruntuhan besar, sehingga bendungan ditinggalkan/ tidak di operasikan kembali.

2) Keruntuhan tipe 2

Keruntuhan besar, tetapi kerusakan bendungan masih dapat diperbaiki dan bendungan dapat dioperasikan kembali.

Kategori keruntuhan tipe 1 maupun tipe 2 dapat dikategorikan sebagai kegagalan tingkat besar dan terjadi disebabkan oleh:

a. Terjadinya peluapan dimana air waduk mengalir melimpasi puncak bendungan yang membentuk rekahan (breach) dan berkembang menjadi keruntuhan total.

b. Terjadinya bocoran besar, deras, dan terpusat di hilir bendungan atau di bangunan yang berkembang dengan cepat serta berwarna atau keruh sesuai dengan kandungan material media aliran, disertai longsoran urugan yang terjadi akibat pengaruh bocoran tersebut.

c. Terjadinya longsoran besar yang memotong puncak bendungan dan menyebabkan pengeluaran air waduk tak terkendali atau menyebabkan berkurangnya tinggi jagaan waduk.

d. Terjadinya pelarutan material fondasi maupun tubuh urugan yang berkembang dengan cepat dan berpotensi menyebabkan keruntuhan bendungan.

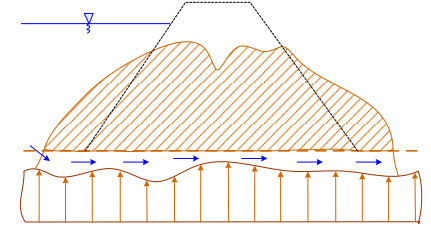

(a)

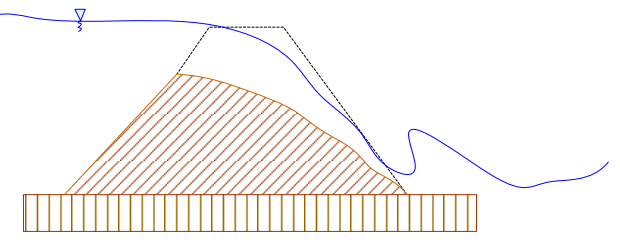

(b)

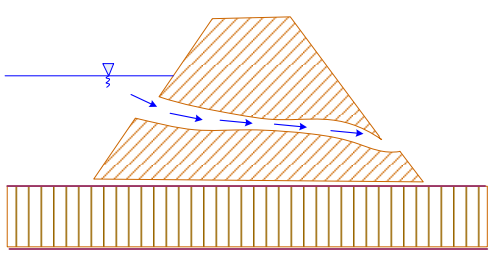

(c)

Gambar 2. Ragam Kerusakan pada Bendungan :

(a) keruntuhan bendungan akibat pelarutan material pondasi;

(b) Pelimpasan;

(c) perembesan air melalui tubuh bendungan menimbulkan erosi buluh.

3) Musibah (accidents) tipe 1

Bendungan sudah beroperasi sementara waktu, sudah dilakukan tindakan perbaikan sebagai pencegahan terhadap keruntuhan termasuk penurunan muka air waduk.

4) Musibah (accidents) tipe 2

Kerusakan telah dipantau/diamati pada masa pengisin pertama dan telah dilakukan tindakan perbaikan sebagai pencegahan terhadap keruntuhan termasuk penurunan muka air waduk. 
Kategori musibah tipe 1 maupun tipe 2 dapat dikategorikan sebagai kegagalan tingkat sedang dan terjadi disebabkan oleh:

a. Terjadinya bocoran besar, deras, dan terpusat di hilir bendungan, atau di bangunan, yang berkembang dengan cepat serta berwarna atau keruh sesuai dengan kandungan material media aliran.

b. Terjadinya lubang erosi (local scouring) dan atau runtuhan tebing akibat arus di kaki hilir bendungan yang berkembang menjadi longsoran.

c. Likuifaksi material karena beban dinamik/gempa.

5) Kerusakan lain

Kerusakan lain dapat dikategorikan sebagai kerusakan ringan dan meskipun bendungan tidak mengalami kerusakan yang serius, namun dapat menyebabkan keruntuhan atau aksiden apabila kondisinya berkembang dan menyimpang atau tindakan perbaikan (remedial works, counter measures) kurang memadai.

\subsection{Penilaian Kondisi}

Indeks kondisi adalah salah satu metode yang banyak digunakan untuk menilai suatu kondisi bangunan. Dari model penilaian kondisi tersebut dapat dipelajari pola kecenderungan penurunan kondisinya (deteriorasi) dan effect akibat dilakukannya tindakan pemeliharaan, rehabilitasi dan penggantian, yaitu tindakan yang dapat meningkatkan kondisi suatu fasilitas infrastruktur. Hal yang paling mendasar dalam mengembangkan model indeks kondisi adalah mengenal sifat dari permasalahannya dan teknik untuk mengkuantifikasi informasi yang bersifat subjektif. Model yang dikembangkan biasanya selalu membutuhkan suatu pengembangan atau suatu penyempurnaan lebih lanjut, agar didapat suatu model penilaian kondisi yang paling mendekati dengan kenyataan.

Metode indeks kondisi gabungan yang dikembangkan pada suatu infrastruktur (Haas and Hudson,1997), merupakan cara untuk menggabungkan dua nilai kondisi komponen atau lebih dengan memberikan faktor pembobotan untuk masing-masing nilai kondisi tersebut. Persamaan metode indeks kondisi gabungan adalah sebagai berikut :

$$
\mathrm{Cl}=\quad \sum_{\mathrm{i}=1}^{\mathrm{i}=\mathrm{n}} \mathrm{Wn} \mathrm{x} \mathrm{Cn}
$$

Keterangan :

$\mathrm{CI}=$ Total nilai kondisi (Indeks kondisi gabungan)

$\mathrm{Wn}=$ Faktor bobot komponen bangunan ke $-\mathrm{n}$

$\mathrm{Cn}=$ Nilai skala indeks kondisi komponen bangunan ke $-\mathrm{n}$ $1,2,3 \ldots . . \mathrm{dst}$

$\mathrm{n}=$ Komponen bangunan ke -

Indeks kondisi gabungan sangat diperlukan oleh para pengelola ditingkat manajemen untuk mengetahui kondisi infrastruktur yang dikelolanya secara keseluruhan dan mengkomunikasikan hasil evaluasinya kepada pengambil keputusan. Hasil evaluasi kondisi digunakan untuk menyusun prioritas program pemeliharaan suatu infrastruktur. Penyusunan prioritas pemeliharaan ini adalah hal yang umum dilakukan pada pihak pengelola (departemen) infrastruktur mengingat adanya keterbatasan anggaran. 


\subsection{Sistem Pemeliharaan Bangunan}

Pemeliharaan bangunan merupakan suatu kegiatan yang sangat penting, agar bangunan tersebut dapat berfungsi dengan baik dan memberikan manfaat yang sesuai dengan rencana teknisnya, sepanjang umur efektif bangunan tersebut. Kegiatan pemeliharaan perlu didahului dengan kegiatan pemeriksaan kondisi infrastruktur, agar kondisi infrastruktur dapat dipantau dan dapat dilakukan tindakan yang diperlukan untuk menyakinkan bahwa infrastruktur berada dalam keadaan aman dan nyaman. Jenis-jenis pemeliharaan meliputi (Soekirno, 2011) :

1. Pemeliharaan preventif/proaktif (Prevention Maintenace/Proactive Maintenance) dilakukan untuk memperlambat atau meniadakan deteriorasi/kerusakan atau kegagalan atau sistem infrastruktur.

2. Pemeliharaan korektif/reaktif (Corrective/Reactive Maintenance), ditujukan untuk memperbaiki kerusakan dan/ atau mengembalikan infrastruktur pada tingkat operasi, fungsi memuaskan, layak setelah terjadi kerusakan.

3. Pemeliharaan menjaga kondisi (oncondition maintenance), merupakan tindakan setelah monitoring untuk mempertahankan kondisi infrastruktur.

4. Pemeliharaan restoral/renovasi ke tingkat semula (Restoration/renovation to Original State), kegiatan pemeliharaan yang segera dilakukan untuk mencegah keruntuhan bangunan infrastruktur.
Bagan alir prosedur pemeliharaan adalah sebagai berikut :

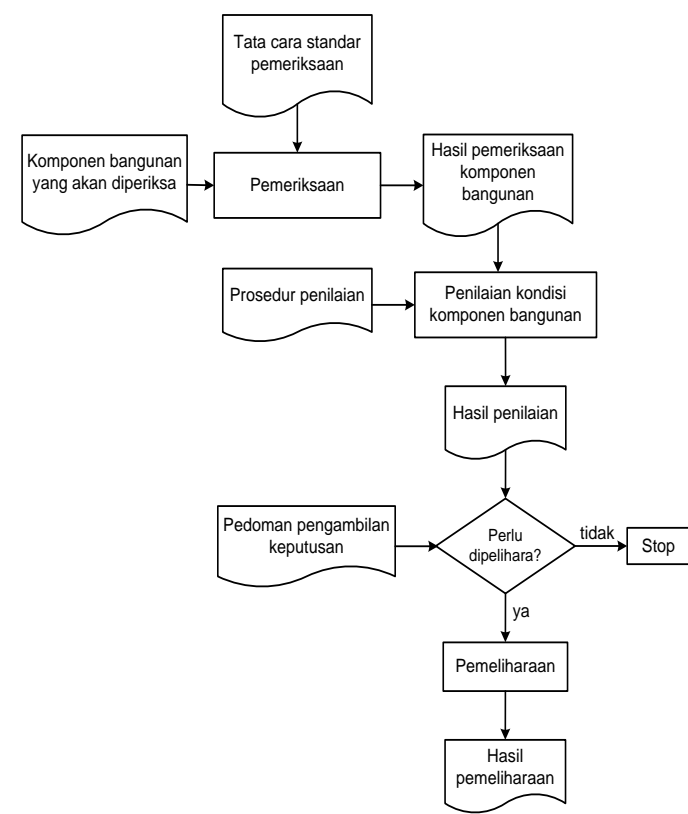

Gambar 3. Prosedur Pemeliharaan Bangunan (Pemeriksaan, Penilaian Kondisi dan Pengambilan Keputusan.

\section{Bendungan Manggar}

Bendungan Manggar dibangun dengan membendung sungai Manggar besar, dengan luas daerah tangkapan adalah 50,00 $\mathrm{km}^{2}$; curah hujan tahunan $1730 \mathrm{~mm}-2539 \mathrm{~mm}$. Tipe bendungan Manggar adalah bendungan urugan tanah homogen didirikan diatas pondasi tanah lunak (soft soil) jenis lempung alluvial yang sangat lemah, dengan tinggi puncak bendungan adalah 13,40 $\mathrm{m}$ dengan kapasitas tampung efektif waduk 14,20 juta $\mathrm{m}^{3}$. Fungsi utama bendungan Manggar adalah mensuplai kebutuhan air baku untuk masyarakat kota Balikpapan dengan kapasitas produksi 900 1/d pada kondisi normal dengan pengambilan periode harian, dan kemampuan produksi pada musim kemarau adalah 160 hari tanpa hujan. Fungsi lain dari bendungan Manggar adalah : fungsi konservasi dan pengendalian air pada waduk, meliputi fungsi dalam 
menyeimbangkan aliran air antara hulu dan hilir sungai, serta memasok air ke kantung-kantung air lain seperti ekuifer (air tanah). Dengan demikian waduk dapat mengendalikan dan meredam banjir pada musim hujan, serta menyimpannya sebagai cadangan pada musim kemarau untuk menghindari kekeringan.

Bendungan Manggar terdiri dari bangunan utama yaitu bendungan utama dan tanggul, waduk, bangunan pengambilan, pelimpah, serta fasilitas pendukung lainnya. Panjang bendungan utama $350 \mathrm{~m}$, sedangkan total panjang tanggul $1.060,00 \mathrm{~m}$. Susunan/ hirarki bendungan Manggar dapat dilihat pada gambar 5, sebagai berikut :

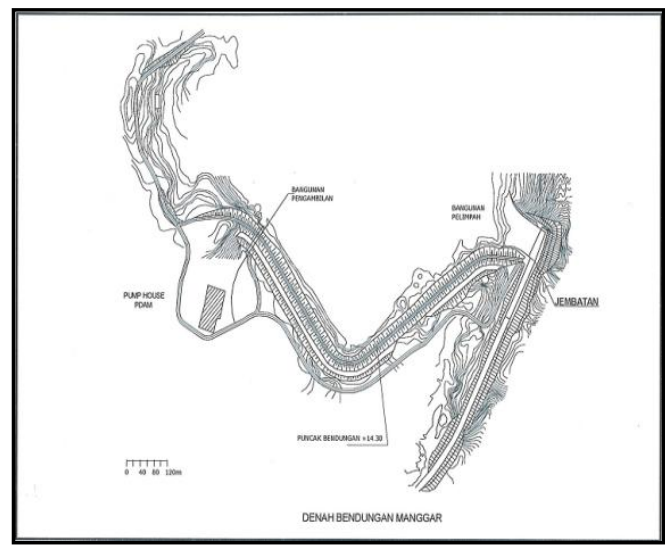

Gambar 4. Denah Bendungan Manggar (Puslitbang SDA, 2010)

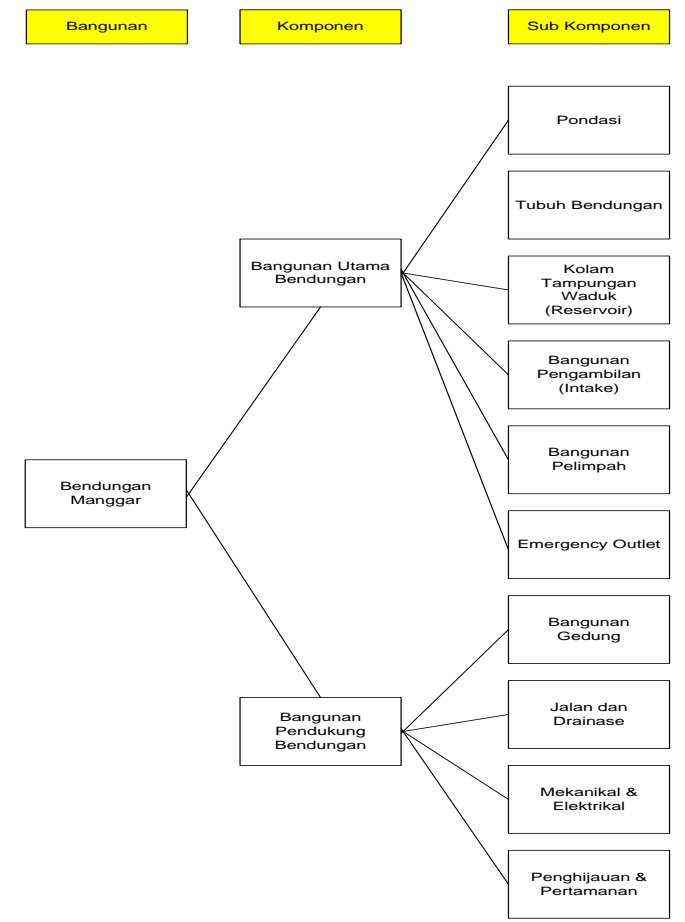

Gambar 5. Hirarki Komponen Bendungan Manggar

\section{Metodologi Penelitian 4.1 Hipotesis Penelitian}

Prosedur penilaian kondisi pelimpah bendungan Manggar memuat tata cara penilaian kondisi dengan metode indeks kondisi gabungan yang dikembangkan oleh Hass dan Hudson (1997), yang sangat berguna dalam melakukan penilaian kondisi infrastruktur, dan sangat membantu dalam penerapan prioritas tindakan pemeliharaan dan perbaikan bangunan dari suatu sistem. Permodelan perhitungan akan memberikan gambaran kondisi kerusakan dari subsub komponen bangunan hingga sistem bangunan yang akan mempengaruhi fungsi sistem secara keseluruhan. Kondisi kerusakan suatu sistem bangunan merupakan gabungan 
kondisi kerusakan dari sub-sub komponennya.

\subsection{Rancangan Penelitian}

1) Menetapkan rumusan masalah dan tujuan penelitian

2) Melakukan kajian pustaka terkait lingkup permasalahan dan tujuan yang telah di rumuskan. Kajian pustaka dilakukan melalui studistudi literatur untuk memperoleh gambaran mengenai bangunan bendungan, komponen, dan subsub komponennya, mempelajari faktor-faktor penyebab terjadinya penurunan kondisi bangunan serta mempelajari metodologi penilaian kondisi bangunan. Selain studi literatur juga dilakukan kajian mengenai bendungan Manggar, yaitu melalui data-data sekunder maupun data-data teknis, yang kemudian menjadi input dalam menyusun suatu prosedur penilaian kondisi pelimpah bendungan Manggar.

3) Penyusunan prosedur penilaian kondisi bendungan, dengan mengambil salah satu contoh kasus komponen pelimpah yang memuat tatacara penilaian dan metodologi yang digunakan untuk menilai komponen pelimpah. Pokok-pokok pembahasan pada prosedur penilaian kondisi pelimpah bendungan Manggar yaitu :

- Membuat hirarki komponen dan sub komponen pelimpah bendungan Manggar.

- Mengidentifikasi kerusakankerusakan pada pelimpah bendungan Manggar yang diperoleh dari data-data primer maupun data-data sekunder.

- Menyusun kriteria kondisi kerusakan, dimana tiap-tiap kondisi diberi penilaian sesuai dengan tingkat kondisinya (indeks kondisi)

- Memberikan bobot pada subsub komponen pelimpah yang kemudian dilakukan penilaian menggunakan metode indeks kondisi gabungan.

4) Kesimpulan dan Saran.

Tahapan-tahapan penelitian yang telah diuraikan dapat dilihat pada bagan alir penelitian sebagai berikut :

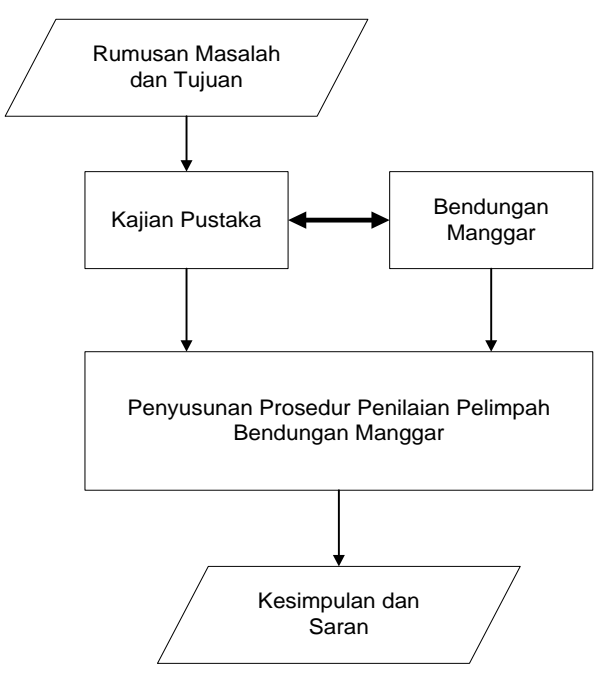

Gambar 6. Bagan Alir Penelitian

\section{Komponen dan Sub Komponen Pelimpah Bendungan Manggar}

Pelimpah pada bendungan Manggar merupakan sub komponen bangunan utama pada bendungan Manggar. Tipe pelimpah adalah pelimpah samping, yang di desain dapat melewatkan debit dengan Q-desain $564,75 \mathrm{~m}^{3} / \mathrm{s}$ (periode ulang PMF), dengan tinggi elevasi mercu $11,30 \mathrm{~m}$, dan panjang mercu 30 m. Komponen pelimpah terdiri dari sub-sub komponen yaitu bangunan hulu, mercu dan bangunan hilir sebagai berikut : 


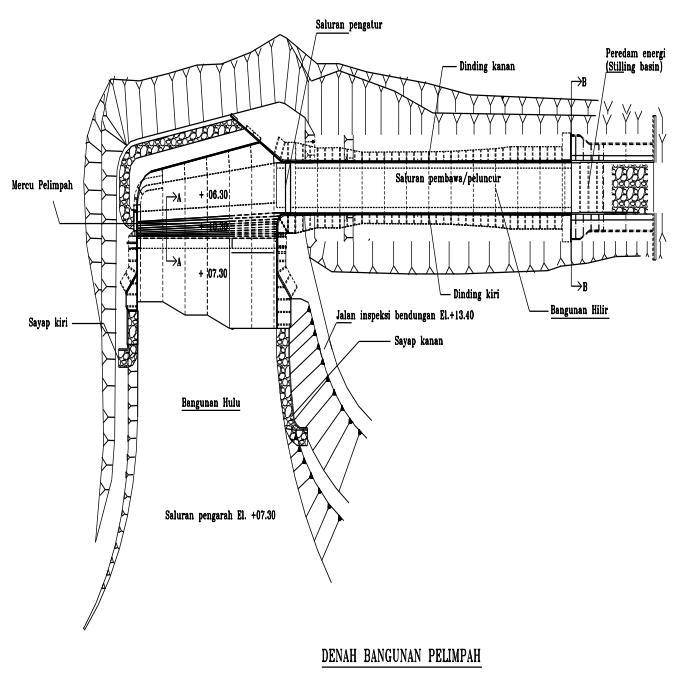

Gambar 7. Denah Pelimpah Bendungan Manggar

Pelimpah bendungan Manggar terbagi menjadi 3 komponen yaitu komponen bangunan hulu, komponen mercu dan komponen bangunan hilir, masing-masing komponen terbagi lagi menjadi sub-sub komponen yang dapat

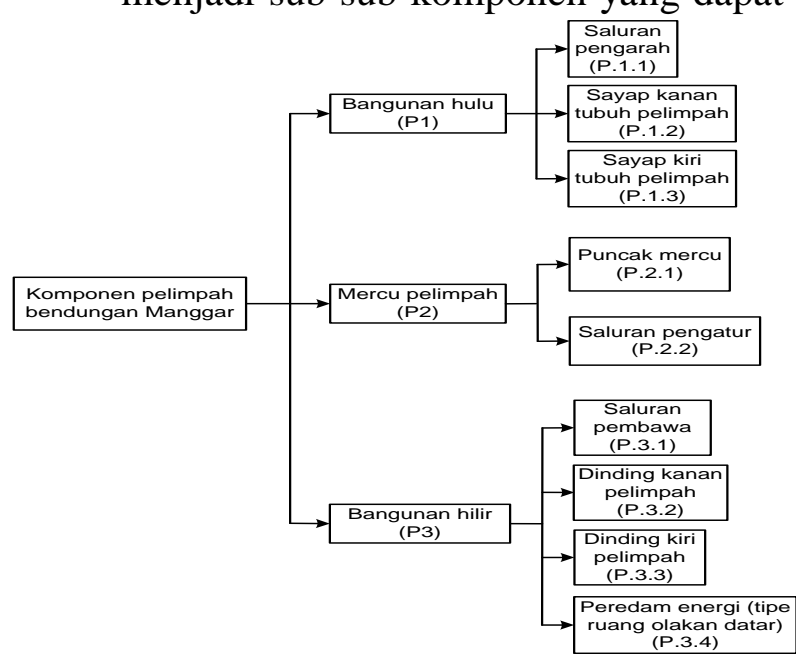

dilihat pada susunan hirarki bangunan pelimpah sebagai berikut :

Gambar 8. Hirarki pelimpah bendungan Manggar

\section{Kategori kondisi kerusakan pada pelimpah bendungan Manggar}

Kriteria kerusakan yang akan dinilai pada komponen bendungan dan komponen pendukungnya, dikelompokkam menjadi beberapa kategori kondisi kerusakan, tujuannya adalah untuk menentukan klasifikasi tingkat kerusakan dari tiap-tiap komponen bendungan. Kriteria kerusakan pada komponen pelimpah dibagi dalam 5 kategori kondisi Tiaptiap kategori kondisi akan di beri nilai atau indeks kondisi berdasarkan tingkat kerusakannya. Pada penelitian ini kriteria indeks kondisi diberikan dari skala $1-5$ yang ditentukan berdasarkan jenis kategori kerusakan yang disusun yaitu terdiri dari 5 kategori, sebagai berikut :

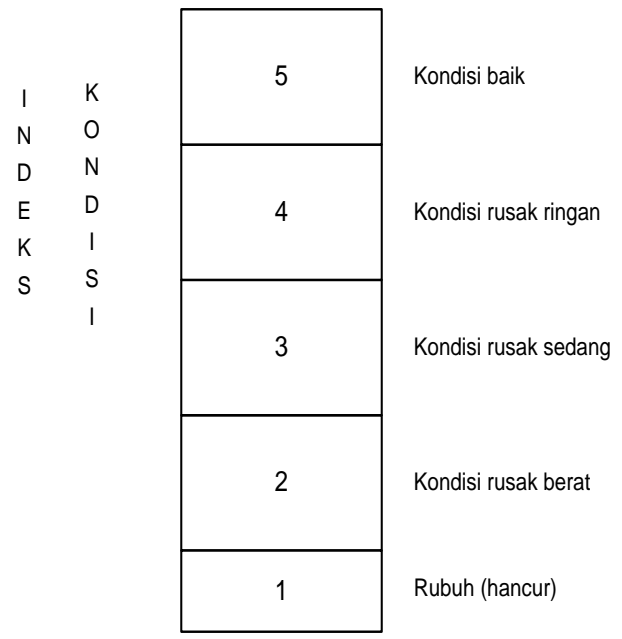

Gambar 9. Nilai Indeks Kondisi

Penyusunan skala indeks kondisi yang disusun pada penelitian ini mengacu pada metode indeks kondisi yang di buat oleh Uzarski (1997), dimana skala yang diberikan dari nilai 0 - 100 dengan 7 tujuh kriteria kerusakan yang masing-masing di beri nilai dengan range antara adalah 15 , sebagaimana telah dibahas pada bab II kajian pustaka. Secara umum tidak banyak literatur-literatur yang memuat tentang penentuan nilai skala indeks kondisi. sehingga pada penelitian ini dilakukan penyesuaian terhadap penentuan indeks kondisi hanya berdasarkan kriteria kondisi kerusakan yang disusun tanpa nilai antara (range), hal ini juga dengan tujuan untuk 
memudahkan dalam menghitung jumlah kerusakan yang di nilai pada bangunan pelimpah dalam penelitian ini.

\section{Prosedur Penilaian Kondisi Pelimpah Bendungan Manggar}

Prosedur Penilaian kondisi yang merupakan suatu prototipe sederhana yang memuat tata cara penilaian kondisi pelimpah bendungan Manggar menggunakan metode indeks kondisi gabungan dengan tahapan sebagai berikut :

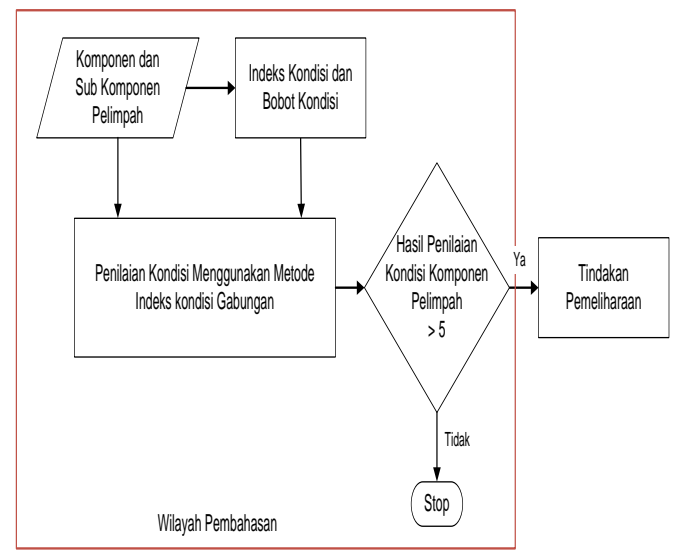

Gambar 9 Prosedur Penilaian Kondisi

Pelimpah Bendungan Manggar

Penilaian kondisi pelimpah dengan metode indeks kondisi gabungan memerlukan input komponen dan subsub komponen pelimpah yang akan dinilai. Tiap sub-sub komponen akan dinilai berdasarkan tingkat kategori kondisi kerusakannya yang disebut dengan penilaian indeks kondisi. Tiap sub-sub komponen juga akan diberikan bobot berdasarkan kontribusi dan kepentingan pengaruh terhadap fungsi sistem (bangunan) pelimpah. Jumlah nilai kondisi pada sub-sub komponen pelimpah akan memberikan gambaran nilai kondisi pelimpah bendungan Manggar untuk kemudian sebagai dasar untuk menentukan penanganan tindakan pemeliharaan yang dibutuhkan.
Penilaian kondisi bangunan pelimpah menggunakan persamaan metode indeks kondisi gabungan sebagai berikut :

$$
\mathrm{Cl}=\quad \sum_{\mathrm{i}=1}^{\mathrm{i}=\mathrm{n}} \mathrm{Wnx} \mathrm{Cn}
$$

Keterangan :

CI = Total nilai kondisi (Indeks kondisi gabungan)

$\mathrm{Wn}=$ Faktor bobot komponen bangunan $\mathrm{ke}-\mathrm{n}$

$\mathrm{Cn}=$ Nilai skala indeks kondisi komponen bangunan $\mathrm{ke}-\mathrm{n}$

$\mathrm{n}=$ Komponen bangunan ke $1,2,3 \ldots . . \mathrm{dst}$

Tabel 1. Perhitungan Indeks Kondisi (CI) Pelimpah Bendungan Manggar

\begin{tabular}{|c|c|c|c|c|}
\hline No & $\begin{array}{c}\text { Komponen } \\
\text { ke=n }\end{array}$ & $\begin{array}{c}\text { Bobot } \\
\text { (Wn) \% } \\
\text { komponen } \\
\text { ke=n }\end{array}$ & $\begin{array}{l}\text { Indeks } \\
\text { kondisi (Cn) } \\
\text { skala 1-5 } \\
\begin{array}{c}\text { komponen } \\
\text { ke=n }\end{array}\end{array}$ & $\begin{array}{c}\text { Total } \\
\text { Nilai } \\
\text { kondisi }\end{array}$ \\
\hline 1 & P1.1 & 4 & 4 & 0.16 \\
\hline 2 & P1.2 & 8 & 4 & 0.32 \\
\hline 3 & P1.3 & 8 & 4 & 0.32 \\
\hline 4 & P2.1 & 40 & 4 & 1.6 \\
\hline 5 & P2.2 & 20 & 5 & 1 \\
\hline 6 & P3.1 & 4 & 4 & 0.16 \\
\hline 7 & P3.2 & 5 & 4 & 0.2 \\
\hline 8 & P3.3 & 5 & 4 & 0.2 \\
\hline 9 & P3.4 & 6 & 5 & 0.3 \\
\hline & & 100 & \multicolumn{2}{|l|}{$\begin{array}{l}\text { Nilai Kondisi } \\
\Sigma \mathrm{Wn} \times \mathrm{Cn} \\
=\end{array}$} \\
\hline
\end{tabular}


Dengan menggunakan penilaian metode indeks kondisi gabungan diperoleh nilai kondisi keseluruhan komponen pelimpah yaitu 4,26. Dari indeks katergori kerusakan $1-5$ dengan nilai kondisi yang diperoleh maka komponen pelimpah termasuk kategori kondisi baik, tetapi terdapat beberapa kerusakan yang dapat dikategorikan kondisi kerusakan ringan.

\section{Kesimpulan}

Dari hasil pembahasan diatas, didapat beberapa kesimpulan sebagai berikut :

1) Prosedur penilaian kondisi pelimpah bendungan Manggar yang disusun, berisi tata cara penilaian kondisi bangunan pelimpah dengan menggunakan metode indeks kondisi gabungan.

2) Tahapan penilaian dengan metode indeks kondisi gabungan yaitu a) menyusun komponen dan sub-sub komponen pelimpah yang akan dinilai. b) Tiap sub-sub komponen akan dinilai berdasarkan tingkat kategori kondisi kerusakannya yaitu terdapat 5 kategori kondisi yang diberi nilai skala 1 - 5 yang disebut sebagai nilai skala indeks kondisi. c) Pemberian bobot berdasarkan kontribusi dan kepentingan pengaruh terhadap fungsi sistem (bangunan) pelimpah. d) Nilai kondisi pelimpah bendungan Manggar merupakan jumlah nilai kondisi sub-sub komponen pelimpahnya.

3) Berdasarkan penyusunan kategori kondisi tingkat kerusakan pada komponen pelimpah diperoleh beberapa kriteria kondisi yang masing-masing kriteria memiliki nilai indeks kondisi yaitu :

a. Kondisi baik dengan nilai indeks kondisi 5

b. Kriteria rusak ringan dengan nilai indeks kondisi 4

c. Kriteria rusak sedang dengan nilai indeks kondisi 3

d. Kriteria rusak parah dengan nilai indeks kondisi 2

e. Kriteria rubuh atau hancur dengan nilai indeks kondisi 1

4) Dari hasil perhitungan nilai kondisi pada sub-sub komponen pelimpah maka diperoleh nilai indeks kondisi pelimpah bendungan Manggar yaitu 4,26. Dari skala kerusakan 1 5 , dengan nilai kondisi yang diperoleh maka keseluruhan komponen pelimpah bendungan Manggar termasuk dalam kategori kondisi baik.

Penurunan nilai kondisi komponen pelimpah mengindikasikan bahwa diperlukan kegiatan-kegiatan pemeliharaan yang bersifat rutin seperti pembersihan material endapan dari tumbuh-tumbuhan yang telah mati dan batang-batang pohon, juga penambalan pada dinding-dinding pelimpah 
yang bocor. Pemeliharaan yang kurang baik dapat mempercepat penurunan nilai kondisi pada bangunan bendungan Manggar.

\section{Daftar Pustaka}

Asdak Chay. 2002 Hidrologi Dan Pengelolaan Daerah Aliran Sungai. UGM, Yogyakarta.

Anonim, 2006, Master Plan PDAM Kota Balikpapan

Anonim. 2006, Master Plan Drainase Kota Balikpapan, Dinas Pekerajaan Umum Kota Balikpapan.

Anonim, 2003 Pedoman Operasi, Pemeliharaan dan Pengamatan Bendungan, Komisi Keamanan Bendungan (Balai Keamanan Bendungan)

Anonim. 2007, Pedoman Operasi dan Pemeliharaan Bendungan Manggar, Balai Bendungan Besar Wilayah Sungai Kalimantan Timur. Balai Keamanan Bendungan, Ditjen Sumber Daya Air, 2003. Pedoman Inspeksi Keamanan Bendungan. Januari 2003

Gabbrielli, E., 2006, Why Integrated Water Resources Management is relevan to water utilities, Diakses 11 oktober 2013, dari http ://www.adb.org/water/operations/200 6/Gabbrielli.pdf.

Hudson, W.R., Haas, R., Uddin, W., 1997, Infrastructure Management

Imonisawa \& Vemuri, 1975, Hidrology \& Hidraulic System.
Kementrian Pekerjaan Umum, 2004, Undang-Undang No. 7 tahun 2004 tentang, Sumber Daya Air, Jakarta.

Peraturan Pemerintah Republik Indonesia Nomor 37/2010 tentang Bendungan (Lembaran Negara RI Tahun 2010 No. 45, Tambahan Lembaran Negara RI No. 5117). Presiden Republik Indonesia, Ditetapkan di Jakarta, tanggal 18 Februari 2010.

Peraturan Pemerintah Republik Indonesia Nomor 92 tahun 2000 tentang Penyelenggaraan Jasa Konstruksi, Jakarta.

Radhi Sinaro,dkk., 2007, Menyimak Bendungan di Indonesia (19102006), Yayasan Kilas Teknologi Konstruksi Indonesia, Jakarta.

Sosrodarsono, Suyono \& Takeda Kensaku, 1989, Bendungan Tipe Urugan, Pradnya Paramita, Jakarta.

Suyono S.,Kensaku Takeda., 1993, Hidrologi untuk pengairan. Pradnya paramita, Jakarta.

Soetjiono, C., 2006. Pengkajian Instrumentasi Geoteknik pada Bendungan Tipe Urugan. Buletin PUSAIR Vol.XV No. 45, Desember 2006, ISSN: 0852-5919

Soetjiono, C., 2010. Perilaku dan Keamanan Bendungan Manggar Kalimantan Timur. Buletin PUSAIR Vol. VI No. 2, November 2010, ISSN: 1829-9644

Soekirno, Purnomo (2011): Manajemen Pemeliharaan Infrastruktur, Program Studi Magister Teknik Sipil, Institut Teknologi Bandung 